\title{
Helmuth Plessner's Social and Political Thought in Light of his Philosophy of Life
}

\author{
- Karol Chrobak -
}

\begin{abstract}
The essay contains an analysis of selected socio-political ideas of Helmuth Plessner. The basic assumption of this study is the existence of a close categorial relationship between Plessner's reflections in The Limits of Community (1924) and in Die Stufen des Organischen (1928). As the interpretative key, the author uses one of the pivotal concepts of Plessner's philosophy of life, namely the category of "border." Showing the adequacy of this category in relation to Plessner's social and political concepts, the essay addresses the issue of the individual-society relationship, the question of social roles and their possible deviations, and the problem of political leadership.
\end{abstract}

Keywords: eccentricity, border, social role, public sphere.

Published online: 31 May 2020

Following the distinction made by Amartya Sen ${ }^{1}$ regarding two models of practicing the theory of justice, in a similar way it is possible to distinguish two approaches to political philosophy. One of them could be characterized as "realization-focused," and the other as "transcendental-focused." The former offers explanations of current political situations by focusing on the functioning of real social institutions. The latter could be described as an attempt to reconstruct the sources and the original conditions of political activity as such. It does not take any position in favour of or against any kind of politics, but continues to formulate its statements in the modus of necessity and unavoidability. In this spirit, for example, Hannah Arendt is a transcendental philosopher, for whom the private and the public sphere are indispensable for settling the fundamental problem of unity in plurality. As we read in The Human Condition, "Plurality is the condition of human action because we are all the same, that is, human, in such a way that nobody is ever the same as anyone else." 2 In a similar manner, Helmuth Plessner also follows

Karol Chrobak

Associate Professor in Philosophy

Department of Sociology

Faculty of Social Sciences and Pedagogy

Warsaw University of Life Sciences - SGGW

ul. Nowoursynowska 166

02-787 Warszawa

Poland

karol_chrobak@sggw.edu.pl

${ }^{1}$ Sen (2009): 7-8.

${ }^{2}$ Arendt (1958): 8. 
the transcendental path of research, since for him reflection on society and politics is inseparably related to the fundamental question: "who are we?"

What Plessner reflects on is not social processes and institutions, which can be historically identified, but fundamental conditions making them altogether possible. Thereby, sociological research begins where Plessner's anthropology ends. Plessner, for example, concludes his anthropological analysis by identifying "natural artificiality" as one of our fundamental characteristics. The object of sociological research emerges only as the result of this natural artificiality, finding its manifestation in a particular society, and under specific historical conditions. This is also why, while talking about Plessner's sociology, we need to remember not to confuse it with what ordinarily falls under this discipline. As Hans Heinz Holz claims, "His sociological subjects continue to be strictly philosophical and differ very essentially from sociology, which comprehends itself as a descriptive-empirical particular science."3

The question of human nature is the pivotal issue of Plessner's philosophy. On the one hand, this question is associated with the fundamental problem of the existence of living beings. In the work Die Stufen des Organischen und der Mensch, Plessner derives all the complexity of human existence from the most elemental components constituting the phenomenon of life. On the other hand, however, his attention is attracted by everything which spreads somehow "above" the human biological condition, which humans give rise to due to a particular attitude, characteristic only to them, towards the world and themselves. These reflections, however, unceasingly draw their inspiration "from below," not only from the anthropological question of human nature, but also from the much more fundamental question "what is life?"

These bottom-up influences are clearly visible in the essay Macht und menschliche Natur, whose subtitle refers directly to the category of anthropology. Plessner, however, is far from favouring any aspect of human existence, be it biological or spiritual. He openly states that understanding the concept of man requires that one abandon the biological discourse. "As the science about the essence of man, which explicitly takes into consideration all his ways of life and forms of manifestation, [anthropology] cannot consequently tolerate too narrow frames of the biological discipline. It embraces the psychological aspect on a par with the spiritual one, the individual one on a par with the collective one, moments coexisting with each other in any time-section on a par with what is historical." 4 Plessner succumbs neither to the naturalistic tendencies of reducing human beings to the biological dimension, nor to the idealistic inclination towards placing their essence in a purely spiritual realm. He opts rather, to use Hans-Peter Krüger's wording, for "the third way," which assumes the methodological equivalence of all aspects of human existence. ${ }^{5}$ A similar position can be traced in the book The Limits of Community (1924). Since this book was written four years before the publication of the treatise Die Stufen des Organischen (1928), in it these ideas appear under the cover of social and political terminology. Plessner produced both these works more or less at the same time. In the foreword to The Limits of Community, he expresses the hope "to publish

\footnotetext{
3 Holz (2003): 134.

4 Plessner (1981b): 147.

${ }^{5}$ Cf. Krüger (2016): 558.
} 
within a year the second volume of [his] theory of knowledge." ${ }^{6}$ Its title was expected to be Plants, Animals, Man - Elements of a Cosmology of Living Form. It should therefore not be surprising that some conceptions and ideas, which we encounter fully finished and elaborated in Die Stufen des Organischen, were already visible in the conceptions presented in The Limits of Community.

For example, Andreas Kuhlmann interprets The Limits of Community in such a way. He writes: "In that earlier writing Plessner makes an attempt to formulate a constitutional description of human personality, without having at his disposal the terminology of his anthropology developed a few years later." ${ }^{\prime 7}$ It seems to me, however, that parallels between the two writings could be drawn much further, and that their affinity could be understood in a much broader sense than the anthropological one alone. What brings the two conceptions closer to each other is a general approach, on the one hand, to the problem of social conditions of the human existence, and, on the other, to the question of the phenomenological structure of the living being.

The purpose of the further analyses is to follow the analogies between both works. The concept of border will be applied to bridge the gap between Plessner's discourse on nature and his socio-political thought. It is important to emphasize these affinities for several reasons. From the historical point of view, this kind of "retrospective" reinterpretation of The Limits of Community allows the developmental continuity of Plessner's philosophy to be exposed. In addition, it reveals the theoretical affinity between his philosophy of life and social philosophy, at the same time providing the opportunity for a better understanding of "the sociological turn" in his thought which occurred later. What is also significant is that by reaching the structural assumptions of his social philosophy, we might try to go "beyond Plessner, still thinking in compliance with his spirit."

\section{Between individuality and community}

In The Limits of Community, Plessner presents us as balancing riskily between the pole of our own "Self" and the pole of community life, among whose "all-encompassing organic connection[s]" 8 one could be willing to become lost and dissolve. Each of these options seems tempting, yet each will be negated if it surrenders to the opposite position. By surrendering to the immediacy of community life, we resign from our individuality: " (...) the person pays to enter the community with the coin of his individual personality." 9 On the other hand, by the excessive immersion in our own individuality and by breaking ties with the community, we are left to our own resources, without sufficient means of support, defence, and protection. As Plessner writes, "The person who traces the source for great values in the development of a being as individual and soul must (...) take upon himself the fate of individualization."10

\footnotetext{
6 Plessner (1999): 42f.

7 Kuhlmann (2002): 16.

8 Plessner (1999): 66.

9 Ibidem: 104.

10 Ibidem: 106.
} 
This dual structure corresponds with the opposition of a closed and open attitude. The attitude of keeping what has been achieved and assimilated could be contrasted with the need to gain and adapt still newer contents for the purpose of sustaining the natural process of development. This structure was even recognized as the fundamental component of social life by Immanuel Kant. "Unsocial sociability" (die ungesellige Geselligkeit) - the paradoxical name he gave it - consists in the opposition of two natural human needs: on the one hand, the need to develop their natural potential, where other actors of the social life are essential, and, on the other, the need to manage his surroundings according to one's own liking, where others might become an obstacle. ${ }^{11}$ One is thereby constantly forced to strike compromises between both needs: the need for "being-at-themself" and the need for otherness.

Precisely the same motivational structure also manifests itself at the level of intergroup processes. As early as the beginning of the 20th century, William Sumner emphasized the close interrelation between the cohesion of a group and its being conflicted with other groups. In the book Folkways, Sumner states that, "The relation of comradeship and peace in the we-group and that of hostility and war towards others-groups are correlative to each other. The exigencies of war with outsiders are what make peace inside, lest internal discord should weaken the we-group for war."12 The tenser the relation between a group and its social surroundings, the more internally coherent it becomes. The analogous interrelation also occurs in the opposite direction: the more open and stable the relations connecting a group with its surroundings, the lower the level of its internal cohesion.

\section{Border}

The confrontation between two systems - an organism and its surroundings, the Self and a community, the we-group and the others-group - requires the existence of an intermediary zone. From the perspective of the organism, the movement going towards the zone is a movement "to the outside," and the movement going from the zone is the movement "to the inside." This zone, since its function is to separate, for obvious reasons must be indifferent towards both separated fields. Therefore, Plessner describes it by the name "border," meaning a structure that does not occupy any space and can be characterized only in a purely functional way. These functions are both logical and ontological. The border plays a logical function since it determines that something residing within the confines is different in meaning from what lies beyond it. The ontological function consists in dividing two separate zones, yet also in connecting them by making it possible for them to interact with each other.

In the following quotation, Plessner focuses on the logical functions of the border: "In this neutral zone (...) directions are colliding (...) with each other, they are [also] originating from it. Through this zone one goes from one field into another. The difference between opposite directions characterizing both fields is still maintained, if after

\footnotetext{
${ }^{11}$ Cf. Holz (2003): 135.

12 Sumner (1906): 12.
} 
passing through this neutral zone the meaning of the direction gets diverted. Since this zone is indifferent towards both directions, and, thereby, cannot occupy any space (...) it is the border." 13 So the logical function of the border involves redefining such fundamental categorial oppositions as: "inside"-“outside," "one's own"-“somebody else's," "familiar" -"unfamiliar" etc. These categories are necessary for understanding not only the fundamental biological functions (assimilation, dissimilation), but also all categories which the human understanding of the world and of the social order in general are based on. The category of border, including all its derivatives, allows both the field of the social reality to be determined, and the inner subcategories of that reality to be defined. The fundamental border of the social life divides what is social from what is proto-social. It is often identified with the border dividing the realm of persons from the realm of animals. Gesa Lindemann shows that such an assumption is premature, while at the same time postulating deanthropologizing sociological thinking. ${ }^{14}$ Other borders go through within the social space, dividing individuals, communities, societies, whole nations and ethnic groups. Such borders have been researched, for example, by Alfred Schütz, when analysing the phenomenon of the stranger. According to him, the stranger is "a border case outside the territory covered by the scheme of orientation current within the group."15 On the social level, therefore, borders give a particular meaning to such categories as "inclusion" and "exclusion," "friend" and "foe," and "safety" and "threat."

Beside its logical function, a border can also perform the function of a real intermediation between systems. In such a case it becomes a buffer making peaceful coexistence and co-functioning of different systems possible. On a biological level, this role manifests itself most clearly in the relationship between an organism and the surroundings. It is therefore instincts that fulfil the elemental functions of the border. Their task it is to soften the tension between the current need and the potential satisfaction, and through them a very particular kind of interpretation of the surroundings takes place. Firstly, it consists in emphasizing all those aspects which are of vital significance for an organism, and in omitting - or rather deadening - all those which are indifferent to its proper functioning. As a result, the dangerous surroundings are "covered" by an environment that is simple to recognize and confidence-boosting. Jakob von Uexküll characterizes the latter as a "self-enclosed unit, which is governed in all its parts by its meaning for the subject." 16 Secondly, instincts automatically initiate the adequate reaction of the organism, as a result shortening the reaction time and relieving the organism of the necessity of taking decisions. Taking into consideration the fact that the adapting function of instincts requires incessant flexibility, we should assume that the border between an organism and the surroundings is the dynamic factor that changes depending on the organism's needs: once moving into the outside (environmental expansion), and another time receding into the inside (environmental implosion).

\footnotetext{
13 Plessner (1981a): 150f.

14 Lindemann (2005).

15 Schütz (1964): 99.

16 Uexküll (2010): 144.
} 


\section{Role}

We witness an analogous kind of intermediary zone in Plessner's conception of social life, presented in The Limits of Community. This is the realm that divides an individual's privacy from the troubling closeness of other actors of social life. It is the domain that "protects" what belongs to the realm of human internality against the inquisitive look of those approaching from the outside. Plessner states that this sphere "(...) seeks to construct its relations impersonally. It nourishes everything that leads from intimacy to distance, from being without restraint to being with restraint, from the concrete individual to the general abstraction." 17 On the one hand, functioning in this sphere protects, but on the other, it is related to the necessity of accepting standard forms of behaviour. By entering this sphere, one assumes a particular role. This can be perceived as a kind of burden, since it gives other people the right to address expectations and demands to the human. The same role, however, becomes a kind of relief and protection, since it provides instructions making it possible to solve almost every problem located within "the field of its expertise." As a result of the roles we perform, the world does not reach us immediately but "(...) through a system of canals and filters, even though its reality does not lose by that anything of its immediate force of manifestation."18

The role serves as a mask the person wears in order to hide their real "Self." As Plessner puts it, "If the person cannot risk being simply and openly what he is, all that remains is the path of being something and appearing in a role." ${ }^{19}$ One lives at the intersection of two contrasting spheres: that which is private and public, and that which is internal and external. Thereby, what belongs to the natural human condition is to continuously protect one's endangered intimacy first and foremost against everything encroaching on it from the outside. In this context, Plessner even uses a military metaphor by comparing the role to "armour that he [man] can wear when entering the battlefield of the public sphere." 20 The necessity of "wearing" some role makes people meet within the public sphere - and to some extent also within the private sphere - always in the position of mutual distance, which, as Plessner writes, "can become neither too wide nor narrow because the rigidity of the respective meaning in whose terms they meet prevents it." ${ }^{21}$ By the same token, social life turns into a kind of game, whose rules everyone must obey, in order to be considered a rightful participant in social reality. This conception seems to be directly related to the idea of "language games," which we find in late Wittgenstein. In both cases, a game is understood deadly seriously, since it is this that gives the basis to the meaning of social life (Plessner) and to that of language (Wittgenstein). In The Limits of Community we read that: “(...) action shows (...) a formal game-like character (...). This is why one act counts as 'valid' and another as 'invalid'." 22 This formulation is very similar to the conception we find in Wittgenstein's Philosophical Investigations. He

\footnotetext{
17 Plessner (1999): 80.

18 Plessner (1983): 187f.

19 Plessner (1999): 133.

20 Ibidem

21 Ibidem: 134.

22 Ibidem
} 
writes that: "What is true or false is what human beings say; and it is in their language that human beings agree. This is agreement not in opinions, but rather in form of life." 23 What the concept of game expresses in both contexts is, on the one hand, the source of meaning, which is interpersonal relations manifesting in individual actions, and on the other, the continuous changeability and dynamism of meaning.

The meaning is not only addressed "to the world," but it also goes reflexively "to the inside." Through the rules one is playing, the human presents themself not only to one's social surroundings, but also to themself. For thinkers representing enlightenment rationalism, romantic socialism, or, finally, naïve Freudianism, such an idea must appear very oppressive. In their opinion, the human is losing touch with one's authentic "Self," putting in its place artificial social conventions. Plessner is of the opposite opinion: he conceives of the human through the prism of hermeneutics as a being who cannot live in any other way than in an understanding one. This understanding not only refers to a particular interpretation of the world of life, but it also influences the way the human interprets themself. Namely, on the grounds of our understanding of the world, we gain access to ourselves; we are to ourselves what we present towards the surrounding reality. Translating this idea into the broader perspective of the philosophy of life, we can state that what constitutes the character of a given organism is not the mysterious essence (Wesen) it contains, but the whole of the relations connecting it with the surroundings. In this conception, the phenomenological approach that Plessner so clearly emphasizes surfaces, as well the anti-metaphysical orientation that he mentions so rarely. He is a philosopher who firmly stands on the ground of experience and only experience, although he conceives of that experience in a much richer and deeper sense than those remaining in natural sciences.

According to Plessner, alienation - meaning the phenomenon whereby access to internality is mediated in what is external, is not a deviation of human nature, but the deepest expression of its openness. The human as a being open to the world recognizes oneself only by observing oneself while in confrontation with the world. As Plessner states, "Self-interpretation and self-experience are being made through other people and things. The way inwards needs a point of support in the outside." 24 The human subject realizes themself not in an abstract sense, but always in embodied form, as localized in a particular point of space-time and determined by particular social and environmental conditions. For this reason, Plessner can be considered the pioneer of the contemporary sociology of the body ("Personality fulfils itself only as embodied," 25 as he writes in Conditio humana), which rejects a simplified, one-dimensional - single-sex, for instance image of man. This image must be completed by, for example, characteristics defining our physical and mental health. As all these characteristics are of fundamental importance in terms of the subject constructing relations with the surroundings (both physical and social), they also translate into the self-image the subject creates. Charles Taylor framed this process accurately as well as pointedly in his conception of recognition. What was expressed in Plessner in "innocent" anthropological language, in Taylor begins to as-

\footnotetext{
23 Wittgenstein (2009): $94^{\mathrm{e}}$.

24 Plessner (1983): 196.

25 Ibidem
} 
sume the attributes of a political act. In the latter's opinion: “(..) misrecognition shows not just a lack of due respect. It can inflict a grievous wound, saddling its victims with a crippling self-hatred. Due recognition is not just a courtesy we owe people. It is a vital human need." 26 The feeling of being recognized does not lie in the hands of an individual subject alone, but belongs to the most fundamental responsibilities of the whole society to develop it and strengthen it. Since, to use Plessner's wording, "a man becomes what he considers himself to be", ${ }^{27}$ it lies within the responsibility of the society to build a healthy self-image into a man. The healthy self-image should be understood first as consistent with a person's self-feeling, and second as ensuring the possibility of developing the potential they possess.

\section{Deviances of social roles}

All kinds of disorders in the subject's self-image must result in the first place from disorders in the relationship between an organism and the surroundings. Generally speaking, these disorders are the consequence of losing the balance between what is internal to an organism and what is external to it. In some cases we can observe excessive encroachment of what belongs to the social realm into the domain of human subjectivity. This kind of implosion results in more rigid behaviour and in restraining authentic expression of the subject. The role is no longer the public expression of what is private, but becomes a function whose meaning is reduced only to contributing to the effective working of the whole society, which is conceived of as a finely tuned machine. In Conditio humana, Plessner writes: "(...) the notion of role, whose foundation is the duality of the private and public sphere, has shifted towards the notion of function, which is unrelated to people and their behaviour. This shift goes unnoticed because in the modern world the more and more dominant idea of rational society of functionaries translates its social activity into pictures of a machine." ${ }^{28}$ At the same time, the domain of subjectivity disappears from the field of vision, and the function takes its place, which, being an abstract set of rules and procedures, is absolutely indifferent to people and the way they behave. From this perspective, the human is perceived only as a component of a larger functional whole: as a functionary of the system. The functionary is a person who has lost the balance in the scale of what is internal and external in favour of the latter extreme. And the whole society, which glorifies its machine-like image, is close to being totalitarian.

It is puzzling, however, that the disorder in the opposite direction - meaning the invasion of subjectivity into the social space - results in very similar political and social consequences. Such an attitude demands reorganization of the whole public sphere in the likeness of the private sphere. Instead of being organized by mutual distance and reserve, the social sphere is expected to be dominated by immediacy and full naturalness of all reactions: of those receiving moral approval as well as those arousing moral objection. This naturalness should originate from the feeling of togetherness, which con-

\footnotetext{
26 Taylor (1994): 26.

${ }^{27}$ Plessner (1983): 116. The next part of this quotation goes as follows: "here emerges his freedom that he has to hold to in order to be a human being."

${ }^{28}$ Ibidem: 201-202.
} 
nects members of a community on the principle either of common origin (a blood-based community) or of common belief (an ideal-based community). Plessner emphasizes that: "No community exists without a blood-based connection between its members; by this is to be understood a biological kinship, as well as a more mysterious harmony of souls." 29 This higher order - based always on some myth of community - becomes the justification for "the violence of an immediately vital and ultimate unveiling." 30 This violence afflicts all individuals, reducing them to the status of automatically and thoughtlessly reacting components of the system. By joining the community, an individual relinquishes their rights almost entirely (including the right to individuality and originality) in favour of realizing higher, collective ideals. Therefore, the sphere where, in principle, the polyphonic voice of all citizens - manifesting their opinions, confronting with one another, and, finally, arriving at a compromise - should find its expression, in the light of the communal life becomes needless, not to say threatening. The sphere is the public sphere. As Plessner puts it, "The community is always an enclosed sphere of intimacy (...). Its essential and necessary opponent is the public sphere [Öffentlichkeit], the background from which it distinguishes itself." 31

In general, both deviances of social roles, consisting in the invasion of the social sphere into the domain of individual subjectivity (for example, being a father reduced to a social function) as well as resulting from the imposition of the logic of private sphere on all types of social relations (for example, social function of being the father of a whole nation), result in totalitarian systems. This is because in both cases a subordination of the subjective sphere to some collective principle takes place. Here it is of secondary importance if it is the rationalistic plan of the machine-like society, or the romantic vision of a society understood either as a family (blood-based community) or as a group united under the banner of the common cause (ideal-based community). In both cases, the subjectivity of an individual, as the ultimate hub where life is given a shape, is subordinated to some higher order, considered as absolute and total. By the same token, " (...) the distinct and enclosed person must surrender himself to such a totality to receive his independence in new form from a supra-ordered source of being." 32

\section{Public sphere}

The public sphere is the first victim of any kind of social radicalisms. They attempt to replace the social order by the communal order. While the former is based on cultivating distance and privacy, the latter aims to introduce in their place immediacy and absolute transparency. The public sphere is thereby a demarcation line, a border. On the one hand, it divides, while on the other, it connects the private sphere with the social sphere. However, if any of these spheres encroaches on another's territory, this is done at the expense of the intermediary public sphere.

\footnotetext{
${ }^{29}$ Plessner (1999): 86.

30 Ibidem: 87.

${ }^{31}$ Ibidem: 91.

${ }^{32}$ Ibidem: 87.
} 
The public sphere is thus an equivalent of the category of border, meaning a neutral area within which smooth adjusting (tuning) of the private to the public occurs. In the first place, it is the sphere where defining and redefining of social roles takes place, as well as the legitimization of a particular social order. In the second place, this sphere protects the private sphere, because all interference ends up at the level of the role, and never reaches what we really "are." In Conditio humana, Plessner writes: "The concept of a social role makes it possible to a man to keep the distance towards his social existence (...): a man, an individual, is never fully what he really ' is'."

This dual characteristic of the public sphere corresponds with the functions fulfilled by a semipermeable membrane, which is in fact the border determining the integrity of all organisms. In relation to the surroundings it works in a twofold way: firstly, in the closing-protecting sense (einschließend-abschirmend), and, secondly, in the opening-mediating sense (aufschließend-vermittelnd). "Membranes are not ordinary surfaces (...). They are intermediary surfaces. In them a body does not simply end, but it is seated (gesetzt) in its relation to the surroundings." ${ }^{34}$ Due to this semipermeable membrane, every living organism is a unique individual as well as a part of the broader whole. In a similar way, the public sphere is the domain where human subjectivity, including its unique individuality, as well as its social identity, with the whole spectrum of rights and obligations, is constituted. It therefore turns out that the concept of the public sphere is not only a political category, but also - or maybe even primarily - an anthropological one.

The main difference between the border of a living organism and the public sphere is the fact that while the functions of the former are established once and for all in the building plan of a given organism (and might at most be disturbed for a while), the functions of the public sphere are incessantly negotiated, questioned, and legitimated. The public sphere is, therefore, a kind of centre of reflection, albeit at a collective rather than an individual level. Consequently, it seems possible to translate the anthropological statements by means of which Plessner describes the individual reflexivity into the context of social and political thought.

According to Plessner, the human is a being that is, but never fully governs itself, or - in other words - is never fully in possession of itself (Ich bin, aber ich habe mich $\left.n i c h t^{35}\right)$. It is to be understood that the human is always something more than it manifests by its presence at a given moment. At the same time, humans look at themselves from the perspective of their ambitions and ideals; who in the process of self-reflection subject themselves to self-assessment and self-criticism. "Man as a living being (das lebendige Ding), which is placed in the centre of his existence, knows about that centre, and experiences it, and, thereby, goes beyond it (über sie hinaus)." ${ }^{36}$ This particular point, from which the human performs the act of reflection, is never where they stand in a particular moment, but within an ideal space difficult to define. Plessner refers to it as ex-centre. The human as the only biological being is able to go beyond itself, to stand in the ex-centre, and to look back from the outside. With this act all self-reflexive processes

\footnotetext{
33 Plessner (1983): 200.

34 Ibidem: 257.

35 Ibidem: 190.

36 Plessner (1981a): 364.
} 
are correlated, such as: self-criticism, self-analysis, and self-presentation. Plessner holds this self-relation to be one which is characteristic of ourselves, one which is key to giving us our exceptional status in the world of nature, "eccentric positionality."

The public sphere, in regard to the functions it performs, seems to correspond strictly to the eccentric perspective. It is also the domain within which the process of reflection takes place. As a result of disputes, debates, and negotiations there emerges something like a collective social self-consciousness. The public sphere - like the ex-centre - is an ideal "place," which can be characterized only by the functions it fulfils. In this case it is the function of filtering, mediating, and finally, legitimizing citizens' opinions and attitudes. The public sphere is therefore the pivot of every democratic society; it is something like the only truly egalitarian parliament. As the centre, it is the sphere where all individual ex-centres meet. It is here that their dispersed voice becomes elevated to the status of an objective, binding decision. Within the public sphere, the individual "Me" turns into the collective "Us," and the subjectivity of the former's opinions turns into the objective validity of the latter's decisions.

Plessner emphasizes that one of the manifestations of the eccentric positionality - beside the world of objects (Außenwelt) and the realm of internal (mental) impressions (Innenwelt) - is the so-called co-world (Mitwelt). ${ }^{37}$ When humans enters this world, they cease to be perceived through the prism of a unique, irreplaceable individual, and become human beings in general. As Plessner writes: "As a member of the co-world every man stands in the same place as any other [man]. In the co-world there exists only One man, and speaking more precisely, the co-world exists only as the One man. He is the absolute point within which everything that possesses a human trait is fundamentally connected, even if that vital foundation breaks up into [the plurality of] individual beings." 38

In this case, the objectivity of values finds its justification not in any universal principle but in the material constitution of us alone. By going beyond ourselves and by entering the ex-centre, we also abandon the natural limitation we are burdened with: our own subjectivity. Plessner, however, does not explain the social mechanism, which allows the plurality of subjective perspectives to be elevated to the level of objective principles and rules. The explanation that the ex-centre is the ultimate guarantee of objectivity, because it represents the abstract point of reflection shared by all people, seems to be insufficient. If it had been considered satisfactory, we would have agreed that the whole of humankind shares the same moral principles. This is, of course, untrue: in different societies, at different stages of their development, and in different political and social contexts, various moral worldviews gained the upper hand. Furthermore, such a solution would also have contradicted Plessner's most fundamental anthropological thesis, according to which the human is an open (offen), inscrutable (unergründlich), and inexhaustible (unausschöpflich) being. So the human is homo absconditus, which means a being who is incapable of being exhaustively cognized in their creative potential, someone who will always be a kind of puzzle to themself. Therefore, what past generations have created and clothed in a nimbus of objectivity is today "to the same extent an

\footnotetext{
${ }_{37}$ More about these three aspects of eccentricity is to be found in Stephan Pietrowicz (Pietrowicz (1992): 429-435) and in Karol Chrobak (Chrobak (2014): 239-257).

${ }^{38}$ Plessner (1981a): 378.
} 
object of respect and reverence as well as of anger (...). Being forced to live, the human as a living being has yet to create for himself the living conditions: artefacts of his past demonstrate the protection shields invented by him, which are all the time under the threat of destruction." ${ }^{39}$ Objectivity is a kind of "prosthesis," which constantly has to be adapted to ever newer challenges which the world poses to the human. But how should such relative objectivity actually be understood?

A potentially promising solution is one which - like Plessner's considerations balances between the anthropological and the political reflection. I am referring here to the conception of ethical objectivity proposed by John Rawls. According to this conception, the criterion of objectivity of a given statement is the existence of the reason that in an open debate could convince reasonable persons of its rationality. While Rawls treats this criterion first and foremost normatively, as being some ideal postulate of deliberative rationality, Jürgen Habermas formulates the very similar conception of discourse ethics, but of a procedural character. In his opinion, what objective means is what has been actually accepted in an open discourse, within which the confrontation of different positions took place and as a result of which they have been agreed. These positions do not differ significantly, ${ }^{40}$ and the conceptions of relative objectivity they offer are very similar. Both claim that objective is everything that in given circumstances - social, historical, and political - could be commonly, in a rationally justified way, considered valid (or, to use Amartya Sen's words: can survive in unobstructed discussion). ${ }^{41}$

This conception breaks with the metaphysical vision of objectivity as originating from some absolute foundation, putting in its place a more or less abstractly conceived discourse. The discourse here is understood as the sphere of meeting - sometimes, of confrontation - of individual opinions, as well as the process that causes them to be invested with objective validity. These functions correspond strictly with the characteristics of the ex-centre. The latter is also the sphere embracing the individual and the collective, as well as the point where the subjective content becomes elevated to the status of objective validity. It is precisely in this sense that one can talk about the public sphere as the eccentric realm, where the human - as the eccentrically positioned being - encounters other people in the perspective of pure reflexivity. Reflexivity as the pure form of an encounter neither imposes nor excludes any potential result. Since the human lives within its own and from its own eccentricity, they can never be absolutely sure which way their existence will follow. In this sense, the human is an open being, in exactly the same way as every debate is open. The human is also inexhaustible, in the same manner as every fundamental question that bothers them is inexhaustible.

\section{The precariousness of human beings and political leadership}

The principle of the inexhaustibility of the human also embraces social discourse. In this case, this crucial category of anthropological thought becomes that of political philosophy. Every debate occurring within the public sphere is by definition an open-ended

\footnotetext{
39 Plessner (1983): 357.

40 Sen (2010): 43.

41 Sen (2004): 349.
} 
process that is impossible to contain within any kind of consensus. This kind of consensus could even have been dangerous, since by necessity it had to downplay the complexity and many-sidedness of human nature. A similar threat is posed by the idea of subjecting human affairs to the arbitrary judgement of science. In the essay Über einige Motive der philosophischen Anthropologie, we read that: "the human can be reached and devoured by scientific objectivity, which turns into objectification, and at the same time leads him to self-alienation from his nature. If he loses himself in it, he himself will become a mere phenomenon." 42 The same is true of democratic debate: the human appears in it as a subject only as long as the question is open; after closing it he becomes only a phenomenon, to which the decision applies.

However, taking into consideration the fact that Plessner was inspired by Carl Schmitt's conception of founding the political on a "friend and foe" opposition, one might expect that he would be quite distant from the idea of an open public debate. In his essay Macht und menschliche Natur, he openly refers to Schmitt's conceptualizations by saying: "Here, the relation friend-foe has been presented (...) as belonging to the essential constitution of the human, and that is right because we refrain from their specific essential description, that we consider them to be the open question, or the power." 43 What transpires through these words is Plessner's belief in freedom (openness) as the source of the political power, which seems to stand in opposition to Schmitt's contempt for liberalism. Plessner applies the latter's strong opposition between friend and foe only as a description of the precarious and unstable condition of the human. They are, namely, always put in "an exposed position" where they must necessarily defend their position against other people's encroachments. The vision of the democratic order as precariously balancing above the chaos of hostile confrontation mirrors the opposition outlined by Plessner in The Limits of Community. In this book, Plessner presents the social order as placed in unstable equilibrium above the community governing itself by the principle of immediacy. If the human had lost this balance and had surrendered to the primitive animal instincts, their individuality would have been destroyed and their dignity would have vanished forever. There is not much exaggeration in these words; Plessner is painting and colouring his philosophical picture in a very dramatic way.

In a situation of constant struggle, there is a need for some instance which might be able to bring to an end all polemics and discussions, and to impose on society its final decision. Plessner therefore resorts to another Schmittian idea, namely, leadership. Only leadership is able to face up to the risk inherent in any decision of a public nature, and could " (...) guide according to maxims of greater security and not according to principles of the trust in reason." 44 Its function is to kill off idle bantering and to arbitrarily settle which option, or which of the adversaries, gains the upper hand in a given case. As Plessner writes in The Limits of Community: "There must be a decision. Without it being the case that somewhere and somehow it is determined to proceed factually in one way and not another, that is, without it being the case that somewhere and somehow action is in fact undertaken, neither the life of the individual person nor the community

\footnotetext{
42 Plessner (1983): 132.

43 Plessner (1981b): 192.

44 Plessner (1999): 177.
} 
is imaginable even for a second." 45 This kind of decision is always taken from a position of power, since in this regard no higher reason applicable to it exists (the decision itself is the principle settling which reason is right, and which is wrong). Although the conception of arbitral political decision can be found in Carl Schmitt's writings, it can also be identified in many other authors. Without reaching back to the very origin of this conception in Thomas Hobbes' philosophy, we can mention Chantal Mouffe ${ }^{46}$ as well as Peter Berger and Thomas Luckmann. ${ }^{47}$ The same postulate of the ultimate authority legitimizing the social order appears in all these authors' work. It does not necessarily have to be one-person ruler, but can also be the voice of the democratic majority, or expertise issued by a few specialists. What is important is that the decision made by this authority temporarily ends all discussions and dispels any doubts.

Mouffe, although following Schmitt's antagonistic way of conceptualizing society, freed her understanding of society from the radicalism of his vision. Namely, instead of following Schmitt, and accepting the "friend-foe" opposition as fundamental to political life, she decided "to think 'with Schmitt against Schmitt'." 48 As a result, she managed to reconcile Schmitt's ideas with the ideals of democratic pluralism, but at the cost of reducing the radicalism of the former ones. In the place of a strong "friend-foe" opposition, where the victory of one side implies the defeat of another one, she gives a much weaker opposition of two adversaries. The triumph of one option, for example in the result of a democratic election, does not mean excluding the other options, but only their being temporary dominated by the win option. These political struggles do not ever end, because they take place within the common symbolic space, which always preserves the possibility of the opposite political option expressing its opinion, and, in the future, fighting for political domination.

Only the agonistic organization of the political sphere provides all citizens with the opportunity for expressing their political opinions, those complying with the mainstream option as well as those going against it. Since only by expressing one's political opinions is the human able to construct their political identity, we can accept that such an open form of making politics should be considered one of the most important postulates of Plessner's political anthropology. He emphasizes very clearly that "Manifestation, exteriorization by no means implies self-alienation, but (...) the chance of being yourself." 49 Therefore, the human cannot be a fully self-conscious participant of political life without having the opportunity to express one's political beliefs. This does not mean, however, that in the absence of legal channels of political expression - for example, in totalitarian systems - no kind of political frustration arises. Nevertheless, this, as it has not been yet elevated to the level of political self-consciousness, finds its expression in only one available form: in aggression and violence. Mouffe thereby admits that the agonistic order is always in danger of slipping into the antagonistic confrontation. As she writes, "(...) the presence of antagonism is not eliminated but 'sublimated'." 50

\footnotetext{
45 Ibidem: 175.

46 Mouffe (2005): 17.

47 Berger, Luckmann (1991): 137-141.

48 Mouffe (2005): 14.

49 Plessner (1983): 204.

50 Mouffe (2005): 21.
} 
The social order is always based on an arbitrarily established ideology (Berger, Luckmann) or on a hegemonic order (Mouffe). The ultimate source of the social order is, therefore, the decision and the requirement of abiding by this decision. Understood like this, in its extrarational and compulsory structure the political decision is reminiscent of instincts, which, although blind and automatic, have the final say in how an animal acts. It thus turns out that - somewhat perversely - the human as a political being does not go beyond their animal nature, but at most grants to the latter a new qualification: the political one.

\section{Conclusions}

Plessner's philosophy is full of striking oppositions, which exist on the principle of dynamic balance. As in the world of nature, every organism is inscribed in a particular environment; within the social world to every human is ascribed a particular set of social roles and functions. The opposition between the human and their role finds its reflection in the tension between the private and the social sphere, between the community seducing with closeness and intimacy, and the society being characterized by distance and the ceremonial game.

Due to all these measures, this philosophy has a unique character: although it is shaped and chiselled by means of incredibly dynamic but precise conceptual oppositions, it constitutes a very coherent and consistent whole. It makes use of this dynamism to express the variable and versatile character of the stream of life, and it needs the coherent and consistent apparatus of concepts to firmly grasp this life's universal determinants. Such categories as "distance," "border," and "eccentricity" do not so much describe as evoke the variability and dynamism of life phenomena. These concepts, as well as those similar to them, constitute a closed conceptual framework, which we can also use successfully today for characterizing the phenomena of psychic, social, and political life.

\section{References}

Arendt, H. (1958), The Human Condition, University of Chicago Press, Chicago.

Berger, P., Luckmann, T. (1991), The Social Construction of Reality. A Treatise in the Sociology of Knowledge, Penguin Books, New York.

Chrobak, K. (2014), Między natura a kultura. Filozofia życia Helmutha Plessnera, Fundacja Aletheia, Warszawa.

Holz, H. H. (2003), Mensch - Natur. Helmuth Plessner und das Konzept einer dialektischen Anthropologie, transcript Verlag, Bielefeld.

Krüger, H.-P. (2016), “Kritische Anthropologie? Zum Verhältnis zwischen Philosophischer Anthropologie und Kritischer Theorie," Deutsche Zeitschrift für Philosophie 64 (4): 553-580.

Kuhlmann, A. (2002), “Deutscher Geist und liberales Ethos. Die frühe Sozialphilosophie Helmuth Plessners," [in:] Plessners 'Grenzen der Gemeinschaft'. Eine Debatte, W. Eßbach, J. Fischer, H. Lethen (eds.), Suhrkamp Verlag, Frankfurt am Main: 15-20.

Lindemann, G. (2005), "The Analysis of the Borders of the Social World: A Challenge for Sociological Theory," Journal for the Theory of Social Behaviour, 35(1): 69-98. 
Mouffe, C. (2005), On the Political, Routledge, London/New York.

Pietrowicz, S. (1992), Helmuth Plessner. Genese und System seines philosophisch-anthropologischen Denkens, Verlag Karl Alber, Freiburg/München.

Plessner H. (1981a), Die Stufen des Organischen und der Mensch, [in:] H. Plessner, Gesammelte Schriften, Vol. IV, Suhrkamp Verlag, Frankfurt am Main.

Plessner H. (1981b), Macht und menschliche Natur, [in:] H. Plessner, Gesammelte Schriften, Vol. V, Suhrkamp Verlag, Frankfurt am Main.

Plessner H. (1983), Conditio humana, [in:] H. Plessner, Gesammelte Schriften, Vol. VIII, Suhrkamp Verlag, Frankfurt am Main.

Plessner, H. (1999), The Limits of Community. A Critique of Social Radicalism, trans. A. Wallace, Humanity Books, New York.

Schütz, A. (1964), Studies in Social Theory, [in:] A. Schütz, Collected Papers, Vol. II, Martinus Nijhoff, The Hague.

Sen, A. (2004), "Elements of a Theory of Human Rights," Philosophy and Public Affairs, 32(4): $315-356$.

Sen, A. (2009), The Idea of Justice, The Belknap Press, Cambridge (MA).

Sumner, W. G. (1906), Folkways. A Study of the Sociological Importance of Usages, Manners, Customs, Mores, and Morals, Ginn and Company, Boston.

Taylor, C. (1994), The Politics of Recognition, [in:] Multiculturalism. Examining the Politics of Recognition, A. Gutmann (ed.), Princeton University Press, Princeton: 25-73.

Uexküll, J. v. (2010), A Foray into the Worlds of Animals and Humans, University of Minnesota Press, Minneapolis.

Wittgenstein, L. (2009), Philosophical Investigations, Wiley-Blackwell, Oxford. 